\title{
МЕДИЧНІ ЕЛЕКТРОННІ РЕСУРСИ УКРАЇНИ
}

\author{
А. А. Крючин, Н. В. Солоніна, Є. А. Крючина' \\ Інститут проблем реєстрації інформації НАН України \\ Національний медичний університет імені О.О. Богомольця 1
}

Представлены данные анализа отображения результатов исследований ученых Украины в отрасли медицины в базах данных научных периодических изданий.

Тривалий час загальновизнаною формою представлення результатів наукових досліджень $є$ публікації наукових статей в журналах. У світі щорічно видається приблизно 3 мільйони наукових публікацій 3 проблем медицини. У системі наукових комунікацій періодичні видання, що складають близько 1/3 документального інформаційного потоку, забезпечують цілий ряд функцій, без яких неможливий розвиток науки: передачу і застосування наукових знань, професійне спілкування і взаємодію науковців. Наукові медичні видання, які роблять свый внесок у систему контролю достовірності й якості публікованих матеріалів, відіграють важливу роль у підвищенні ефективності медичної науки $[1,2]$.

Враховуючи величезні обсяги нової медичної інформації, необхідність швидкого розповсюдження наукової інформації і обговорення опублікованих робіт, форма представлення наукових публікацій буде швидко змінюватися, і перевага належитиме електронним виданням. Будуть розвиватися міжнародні системи електронної публікації наукових робіт [2-5].

В Україні видається 168 наукових медичних періодичних видань, які визнані фаховими. Спостерігається постійне збільшення кількості наукових медичних періодичних видань (за останні 10 років засновано понад 67 нових видань) та виділення більш вузькоспеціалізованих видань. Вузькоспеціалізовані видання складають близько 60 \% від загальної кількості медичних видань.

Загальна кількість наукових статей, які публікуються щорічно, становить 8-9 тисяч. Наукові публікації в галузі медицини складають приблизно $9 \%$ від загальної кількості наукових публікацій у фахових виданнях (рис. 1).

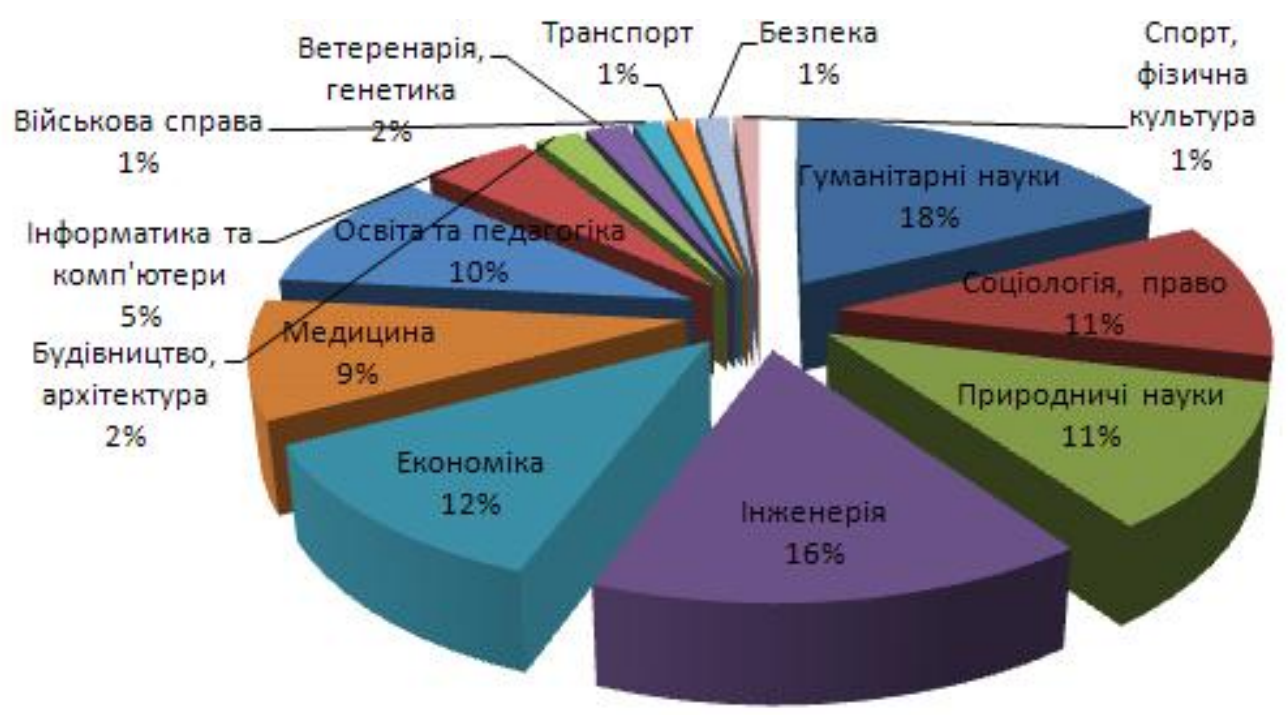

Puc. 1. Розподіл наукових публікацій за галузевими дослідженнями.

Необхідно зазначити, що розподіл публікацій вчених України та Росії за напрямками наукових досліджень, представлених у світових базах даних наукових видань, суттєво відрізняється від розподілу публікацій, представлених у фахових виданнях України. На цей факт неодноразово звертали увагу науковці $[6,7]$.
У базі даних Scopus на 1995-2011 роки представлено 1899 наукових публікацій в галузі медицини, що становить 0,031% від загальної кількості публікацій в цьому науковому напрямку, тоді як публікації в галузі матеріалознавства становлять 11 \%, в галузі фізики $10 \%$, комп’ютерних наук (Computer Science) становлять $4 \%$. Частина публікацій в галузі медицини

(C) А. А. Крючин, Н. В. Солоніна, С. А. Крючина 
(включаючи фармакологію) складає 2,67 \% від загальної кількості публікацій вчених України, представлених в базі даних Scopus. Українські автори не часто посилаються на власні роботи (показник самоцитування 1,88$)$.

За умов первинних накладів вітчизняних наукових видань, обмежених можливостей придбання бібліотеками таких видань (самим бібліотекам складно обробляти постійно зростаючу кількість видань), а, головним чином, - необхідності оперативного ознайомлення з результатами досліджень, актуальним стає представлення читачам електронних версій наукових журналів. Вважають, що представлення результатів наукових досліджень в електронному вигляді найближчим часом стане головною формою [3-5]. Доцільно зберегти сувору систему експертної оцінки, відбору та обробки матеріалів, які здійснюють відомі вчені і фахівці за відповідними розділами науки. Така селективність відсутня в багатьох базах електронних препринтів, що заважає задачі вченого з пошуку в комп'ютерних мережах важливої інформації [3]. Однією 3 умов включення наукового журналу до світових баз даних (наприклад до бази даних Scopus [9]) є представлення електронної версії журналу.

Збільшенню кількості публікацій вітчизняних вчених в галузі медицини, що представляються в світо- вих базах даних, буде сприяти дотримання загальновизнаних у світі вимог до документів, що подаються до редакцій журналів, входження самих журналів до міжнародних систем обробки і впровадження наукових видань [9].

У Національній бібліотеці України імені В. І. Вернадського представлені у відкритому доступі 1802 фахових періодичних видання України починаючи 3 2003 року. Кількість звернень до цієї бази даних щодня перевищує 300 тисяч [10].

В таблиці 1 наведено перелік медичних журналів, до повнотекстових версій яких найчастіше звертаються читачі. Мала кількість звернень до деяких видань може бути пов'язана 3 непредставленням останніх номерів журналів в базі даних наукової періодики України. Слід зазначити, що кількість звернень до багатопрофільних журналів значно більша.

Частково вирішенню проблеми донесення інформації, представленої у наукових журналах, до широкої наукової громадськості сприяє видання реферативних журналів, формування баз даних реферативної інформації. В українському реферативному журналі «Джерело» представляється інформація про публікації в 80 наукових журналах. Кількість журналів, статті з яких реферуються в журналі «Джерело», постійно зростає.

Таблиця 1. Наукові медичні журнали України, до повнотекстових версій яких найчастіше звертаються читачі

\begin{tabular}{|c|c|c|c|}
\hline Назва журналу & $\begin{array}{c}\text { Засновник, } \\
\text { рік заснування }\end{array}$ & Тематика & $\begin{array}{c}\text { Кількість } \\
\text { звернень } \\
\text { (відсоток від } \\
\text { кількості } \\
\text { звернень) } \\
\text { за } 2012 \text { р. }\end{array}$ \\
\hline $\begin{array}{c}\text { Український медичний часопис } \\
\text { Науково-практичний } \\
\text { загальномедичний журнал }\end{array}$ & Видавництво «МОРІОН», 1997 & медичні науки & $9401(3,53)$ \\
\hline $\begin{array}{c}\text { Український медичний } \\
\text { альманах Науково-практичний } \\
\text { журнал }\end{array}$ & $\begin{array}{l}\text { Луганський державний медичний університет, } \\
1998\end{array}$ & медичні науки & $7275(2,55)$ \\
\hline Буковинський медичний вісник & $\begin{array}{l}\text { Буковинський державний медичний } \\
\text { університет, } 1997\end{array}$ & медичні науки & $6382(2,29)$ \\
\hline $\begin{array}{l}\text { Український журнал хірургії } \\
\text { Науково-практичний журнал }\end{array}$ & $\begin{array}{l}\text { Донецький національний медичний } \\
\text { університет імені М. Горького, Асоціація } \\
\text { хірургів Донецької області, } 2007\end{array}$ & хірургія & $5534(2,17)$ \\
\hline Запорізький медичний журнал & $\begin{array}{l}\text { Запорізький державний медичний } \\
\text { університет, } 1999\end{array}$ & медичні науки & $4820(1,6)$ \\
\hline Практична медицина & $\begin{array}{l}\text { Львівський національний медичний } \\
\text { університет імені Данила Галицького; ПП } \\
\text { “ПМ”, } 2010\end{array}$ & медичні науки & $4546(1,68)$ \\
\hline $\begin{array}{c}\text { Таврический медико- } \\
\text { биологический вестник }\end{array}$ & $\begin{array}{l}\text { Кримський науковий центр НАН України і } \\
\text { МОН України у справах науки та технологій; } \\
\text { Кримський державний медичний університет } \\
\text { iмені С.І. Георгієвського, } 1998\end{array}$ & $\begin{array}{l}\text { медичні, } \\
\text { біологічні } \\
\text { науки }\end{array}$ & $4078(1,63)$ \\
\hline
\end{tabular}


Продовження табл. 1

\begin{tabular}{|c|c|c|c|}
\hline Назва журналу & $\begin{array}{c}\text { Засновник, } \\
\text { рік заснування }\end{array}$ & Тематика & \begin{tabular}{|c} 
Кількість \\
звернень \\
(відсоток від \\
кількості \\
звернень) \\
за 2012 р.
\end{tabular} \\
\hline $\begin{array}{c}\text { Актуальні проблеми } \\
\text { транспортної медицини }\end{array}$ & $\begin{array}{l}\text { Український науково-дослідний інститут } \\
\text { медицини транспорту МО3 України, } 2005\end{array}$ & $\begin{array}{c}\text { медичні, } \\
\text { біологічні } \\
\text { науки }\end{array}$ & $3852(1,6)$ \\
\hline Современная стоматология & Издательство Эксперт ЛТД, 1997 & стоматологія & $3506(1,39)$ \\
\hline $\begin{array}{l}\text { Питання експериментальної та } \\
\text { клінічної медицини }\end{array}$ & $\begin{array}{l}\text { Донецький національний медичний } \\
\text { університет імені М. Горького, } 1997\end{array}$ & медичні науки & $3293(1,11)$ \\
\hline $\begin{array}{c}\text { Журнал Національної академії } \\
\text { медичних наук України } \\
\text { Науковий журнал Президії } \\
\text { НАМН України }\end{array}$ & НАМН України,1995 & $\begin{array}{c}\text { теоретична, } \\
\text { клінічна і } \\
\text { профілактична } \\
\text { медицина }\end{array}$ & $3195(1,42)$ \\
\hline Одеський медичний журнал & $\begin{array}{l}\text { МОЗ України, Одеський національний } \\
\text { медичний університет, } 1997\end{array}$ & $\begin{array}{c}\text { медицина, } \\
\text { біологія та } \\
\text { фармація } \\
\end{array}$ & $3117(1,00)$ \\
\hline $\begin{array}{l}\text { Клінічна та експериментальна } \\
\text { патологія }\end{array}$ & $\begin{array}{l}\text { Буковинський державний медичний } \\
\text { університет, } 2002\end{array}$ & медичні науки & $2926(1,05)$ \\
\hline Травма & $\begin{array}{l}\text { Донецький національний медичний } \\
\text { університет імені М. Горького, НДІ } \\
\text { травматології та ортопедії, } 2000\end{array}$ & $\begin{array}{c}\text { травматологія } \\
\text { та ортопедія }\end{array}$ & $2811(1,01)$ \\
\hline $\begin{array}{c}\text { Актуальні проблеми } \\
\text { акушерства і гінекології, } \\
\text { клінічної імунології та } \\
\text { медичної генетики }\end{array}$ & $\begin{array}{l}\text { Луганський державний медичний університет, } \\
1999\end{array}$ & $\begin{array}{c}\text { акушерство та } \\
\text { гінекологія }\end{array}$ & $2693(0,95)$ \\
\hline Перинатологія і педіатрія & $\begin{array}{l}\text { Інститут педіатрії, акушерства та гінекології } \\
\text { НАМН України, } 1999\end{array}$ & $\begin{array}{c}\text { перинатологія i } \\
\text { педіатрія }\end{array}$ & $2664(0,94)$ \\
\hline $\begin{array}{c}\text { Ортопедия, травматология и } \\
\text { протезирование }\end{array}$ & $\begin{array}{l}\text { Донецький національний медичний } \\
\text { університет імені М. Горького, Заславський } \\
\text { Олександр Юрійович, } 1927\end{array}$ & $\begin{array}{c}\text { ортопедія, } \\
\text { травматологія }\end{array}$ & $2600(0,90)$ \\
\hline Здоров'я дитини & $\begin{array}{l}\text { Донецький національний медичний } \\
\text { університет імені М. Горького, Заславський } \\
\text { Олександр Юрійович, } 2006\end{array}$ & & $2548(0,91)$ \\
\hline Вісник стоматології & $\begin{array}{l}\text { Iнститут стоматології НАМН України, } \\
\text { Асоціація стоматологів України, Одеська } \\
\text { обласна клінічна стоматологічна поліклініка, } \\
1994\end{array}$ & Стоматологія & $2250(0,76)$ \\
\hline $\begin{array}{l}\text { Експериментальна і клінічна } \\
\text { медицина }\end{array}$ & $\begin{array}{l}\text { Харківський національний медичний } \\
\text { університет, } 1998\end{array}$ & медичні науки & $2182(0,81)$ \\
\hline $\begin{array}{c}\text { Клінічна анатомія та } \\
\text { оперативна хірургія }\end{array}$ & $\begin{array}{l}\text { Буковинський державний медичний } \\
\text { університет, } 2002\end{array}$ & хірургія & $2147(0,70)$ \\
\hline Клінічна фармація & $\begin{array}{l}\text { МОЗ України; Державне підприємство } \\
\text { "Державний фармакологічний центр МОЗ } \\
\text { України"; Національний фармацевтичний } \\
\text { університет, } 1997\end{array}$ & медичні науки & $1919(0,69)$ \\
\hline $\begin{array}{c}\text { Вісник Вінницького } \\
\text { національного медичного } \\
\text { університету } \\
\end{array}$ & $\begin{array}{l}\text { Вінницький національний медичний } \\
\text { університет імені М.I. Пирогова, } 1994\end{array}$ & медичні науки & $1549(0,55)$ \\
\hline $\begin{array}{c}\text { Актуальні питання } \\
\text { фармацевтичної та медичної } \\
\text { науки та практики }\end{array}$ & $\begin{array}{l}\text { Запорізький державний медичний } \\
\frac{\text { університет, }}{2009}\end{array}$ & $\begin{array}{c}\text { фармацев- } \\
\text { тичні науки, } \\
\text { медичні науки }\end{array}$ & $1023(0,42)$ \\
\hline
\end{tabular}


Висновки. Включення до активного наукового обігу наукових публікацій у галузі медицини можливе за умов представлення електронних версій пуб-

\section{Лiтература}

1. Шарабчиев Ю. Т. Количество и качество публикуемых результатов научных исследований в медицине / Ю. Т. Шарабчиев // Медицинские новости. -2003. - №12. C.18-20.

2. Шарабчиев Ю. Т. Научные медицинские журналы Беларуси: какие они? / Ю. Т. Шарабчиев, О. С. Гук // Медицинские новости. - 2012. - №3. - С.11-18.

3. Аксентьева М. С. Особенности издания традиционного журнала в электронной и печатной форме. Проблемы и перспективы на примере опыта издания журнала “Успехи физических наук" [Электронный ресурс ] - Режим доступа http://www.gpntb.ru/win/inter-events/crimea95/report/ rep069 r.html.

4. Ибрагимова И. Электронные медицинские ресурсы в Интернете / И. Ибрагимова // Международный журнал медицинской практики. -2005. - № 2. - С. 76-80.

5. Юхимец В. А. Медицинские электронные ресурсы / В. А. Юхимец, Т. Б. Рагузина, Г. Л. Гуменюк // Астма та алергія. -2011 . -№ 1 . лікацій в базах даних, оперативного розміщення їх на сайтах журналів, співпраці з реферативними виданнями.

6. Мриглод І. Наука України у світовому інформаційному просторі / Мриглод І., Мриглод О. // Вісник національної академії наук. -2007. - № 10. - С. 3-18.

7. Бондарь В. В. Сколько научных публикаций в год выходит в РФ / Бондарь В. В., Григорян Л. А. // Материалы 8-ой Международной конференции «Актуальные проблемы информационного обеспечения, аналитической и инновационной деятельности», 28-30.11.2012., Москва.

8. SJR Country Rankings. Scopus. [Електронний ресурс ]Режим доступу http://www.scimagojr.com/ countryrank.php?area $=1700 \&$ category $=0 \&$ region $/$.

9. Кирилова О. В. Подготовка российских журналов для зарубежной аналитической базы данных Scopus: рекомендации и коментарии. [Электронный ресурс ]-Режим доступа.- http:/elsevierscience.ru/info/add-journal-to-scopus/. 10. Національна бібліотека України імені В. І. Вернадського. Електронний архів наукових періодичних видань України. [Електронний ресурс ] - Режим доступу http:// www.nbuv.gov.ua/. 